\title{
ХКН-ЫН ХVIII ИХ ХУРАЛ БОЛОН ХЯТАДЫН НИЙГЭМ-ЭДИЙН ЗАСГИЙН ХӨГЖЛИЙН ТАЛААРХ ОРОСЫН ЭРДЭМТЭН, СУДИААЧДЫН БАЙР СУУРЬ
}

Ч.Батцэцэг*

\section{Товч утга:}

$7 \mathrm{KH-ын} \mathrm{XVIII} \mathrm{их} \mathrm{хурлын} \mathrm{үйл} \mathrm{явц,} \mathrm{онциог,} \mathrm{ач} \mathrm{холбогдоп,}$ “тав дахь үеийн" шинэ удирдпага, Хятадын нийгэм1 -эдийн засгийн хөгжлийн асуудпаар гадаадын хэвлэл, мэдээппийн хэрэгспэлээр нийтпэгдсэн материал, Оросын эрдэмтэн, судлаачдын байр суурь, үзэл бодлыг авч үзлээ.

Tүпхуүр үгс: ХKН, их хурал, шинэ удирдпага, улс төр, эдийн засаг, нийгмийн хөгжил

2012 оны 11 дүгээр сарын 8-14-ний хооронд хурапдсан ХKН-ын XVIII их хурал нь арав дахь жилдээ төр, засаг барьж буй удирдлагаа шинэчлэх улмаар энэхуү шинээр сонгогдсон тав дахь уеийн удирдпага Хятадын хөгжлийн ирэх 10 жилийн төлөв байдлыг тодорхойлж, эдийн засгийн хөгжлийн арга хэлбэрийг шинэчилж, өөрчпөптийг түргэсгэх зорилтыг хэрэгжуүпэх болно. Иймээс дэлхий нийтийн анхаарпын төвд байж, хэвпэл мэдээппийн хэрэгспэпүуд өөр өөрийн сувгаар, өөр өөрийнхөө өнцгөөс мэдээлж, гадаадын эрдэмтэн судлаачид Хятадад болж буй үйл явдлын талаар дүгнэлт хийж, санаа бодпоо ипэрхийпсээр байна.

БНХАУ-ыг 1949 оны аравдугаар сарын 1-нд тунхагпаснаас хойшхи тав дахь үеийн удирдпагыг ХKН-ын 82 сая гишүүнийг төлөөлсөн 2325 төлөөлөгч энэ их хурлаас тодруулсан юм. Хятадын төр, засгийн удирдпагад хэн хэн байхыг их хурлын өмнө хурапдсан ХКН-ын Төв Хорооны допдугаар бүгд хурлаар үндсэндээ нэрлээд байв. Их хурпаар хэлэпцэн тогтоод 2013 оны гуравдугаар сард Бух Хятадын Ардын Төлөөлөгчдийн Их Хурлаар /БХАТИХ/ шинэ удирдпагад бурэн эрхийг нь олгож батпамжилжээ. Юуны өмнө ХКН-ын Төв Хорооны Байнгын хорооны 9 гишүүний орон тоог

"Ч.Батцэцэг - Олон улс судиалын хурээлэнгийн эрдэм шинжилгээний ахлах ажиптан, доктор (Ph.D) 
7 болгон цөөлсөн байна. Байнгын хорооны бүрэлдэхуүнд ХKH доторхи бүпэгпэпүүдээс "хувь тэнцүу" оруупахаар бопсныг өөрчпөлт шинэчпэпийн шинж хэмээн гадны ажигпагчид харж байлаа. Хятадын тав дахь уеийн удирдагчдын бүрэпдэхуүнд БНХАУ-ын дэд дарга Си Зиньпин, Төрийн зөвлөлийн Ерөнхий сайдын орпогч Пи Кэцян, Ерөнхий сайдын санхүу эрхэлсэн орпогч Ван Цишань. Намын дээд удирдлагын төлөөлөл болох Пю Юньшань, Пи Юаньчао, Жан Дэзян, Жан Гаоли нар оров. Тэднээс Си Зиньпин улсаа даргалж. Пи Кэцян Төрийн Зөвпөлийн Ерөнхий сайд бопох нь тодорхой боппоо хэмээн Agence France Press /AFP/ мэдээпж байсан юм.

Шинэ удирдпагын нэрсийн жагсаалтыг БНХАУ-ын дарга ХУ Зиньтао, туүний залгамжлагч хэмээгдэж буй БНХАУ-ын дэд дарга Си Зиньпин, Хятадын гурав дахь үеийн тэргуүн Зян Зэминь нар батпамжилсан байна. БХАТИХ-ын 12 дугаар чуупган дээр Си Зиньпиний нэрийг нууцаар сонгожээ. Бүх төлөөлөгчиийн саналыг тоолсны дараа бараг 3000 төлөөлөгчөөс нэг хүн татгалзаж, гурван хүн түдгэлзсэн нь илэрчээ. Энэ талаар Москвагийн улсын их сургуупийн /МГУ/ Орос, Хятадын харилцааны судалгааны төвийн удирдагч Евгений Зайцев "Хятад упсад ирээдүйн удирдагчдын нэр нь албан ёсоор зарлахаас хамаагүй өмне тодорхой бопдог тийм улс төрийн тогтольоотой. Си Зиньпин ХКН-ын ерөнхий нарийн бичгийн дарга болно гэдэг нь хэдэн жипийн өмнөөс тодорхой болсон боловч тэрээр дөнгөж 2012 оны 11 дүгээр сард апбан ёсоор энэ суудпыг эзэппээ. БХАТИХ-ын чуупга, ХКН-ын их хурал гэх мэт иймэрхуү үйл ажиплагаан дээр эрс өөрчлөлт, санамсаргүй зуйл гарахгүй" гэж тэмдэгпээд, “жишээ нь индэр дээр Хятадын Борис Ельцин гарч ирээд упс орныг үндсээр нь өөрчлөх цаг үе ирлээ гэх мэт санамсаргүй зүйл гарах магадлап маш бага. Энэ үйл ажиплагааг маш нарийн төлөвлөж, хянуур бэлтгэдэг. Хэрвээ ямар нэгэн санамсаргүй зүйл гарвал түүнийг ХКН-ын удирдагчид өөрсдөө санаачилсан байдаг юм" хэмээн ярилцлага өгчээ.

Мөн БХАТИХ-ын 12 дугаар чуупган дээр нөхөр Си Зиньпинийг Хятадын Цэргийн Төв Зөвлөлийн тэргүүнээр сонгс знн байна. Харин 11 дүгээр сард тэрбээр ХКН-ын Төв Хорооны Цэргийн Зөвлөлийн даргаар сонгогдсон. Өөрөөр хэлбэл Си Зиньпин армийг улсын талаас нь ч намын талаас нь ч хянаж байгаa юм. Хамгийн сонирхолтой нь тэр асар богино хугацаанд төрийн бүх эрхийг гартаа авч чадлаа. Жишээ нь: Ху Зиньтао намын тэргүунээр сонгогдсноосоо хойш хоёр жилийн дараа п ерөнхий дээд командпагч болж байсан билээ. Харин Си Зиньпин өөрийн залгамжлагчаасаа ихэд ялгаатай 
байгаа юм. Ялангуяа Си Зиньпиний улс төрийн хэв маяг нь түүнийг ХКН-ын Ерөнхий нарийн бичгийн даргаар сонгосон өдрөөс эхлэн ажиглагдсан гэж "Власть" сэтгуулийн ерөнхий редактор Александр Габуев ярьж байна. Тэрээр Төв Хорооны Байнгын хорооны шинэ бүрэлдэхуүнийг танилцуупах ёслопын ажиплагаан дээр сэтгуүпчдэд зориулж товч илтгэл тавьсан. УГ нь хуучин ёсоор бол Төв Хорооны Байнгын хорооны гишуүд бүгдээрээ индэр дээр гарч ирээд дув дуугүй зогсож, сэтгүүпчдийн өмнөөс инээмсэгпэж байгаад зургаа татуупаад арипж өгдег байсан. Харин энэ удаа Си Зиньпин товч үг хэлсэн бөгөөд түунд марксизм, социализм зэрэг үзэл суртпын үг хэлпэг огт байгаагүй. Үүний оронд тэр ажипгүйдэл, эдийн засгийн хөгжлийн уцаашрал, тэтгэврийн тодорхой систем байхгүй байгаа, авилга газар авч байгаа зэрэг хүмүусийн сэтгэлийг бодитойгоор зовоож байгаа асуудлыг ярив. Түүний засгийн газар ойрын 10 жилд эдгээр асуудлуудыг шийдвэрлэхийн төлөө ажиплах болно гэж Си ампасан хэмээн Александр Габуев хэлсэн байна.

Нөгөөтэйгүур БНХАУ-ын дарга Ху Зиньтао иптгэл тавих үеэр биеэ хэрхэн авч явж байсан талаар гадаадын сэтгүупчид түүний дотор Бээжинд ХКН-ын их хурлын ажиплагааг сурвалжилж байсан "Оросын дуу хоопой" радиогийн тоймч Игорь Денисов ХКНын XVIII их хурал опон арван биш, олон зуун жилийн уламжлапд хандаж байгаад анхаарпаа хандуулсан байна.

БНХАУ-ын дарга Ху Зиньтао Ерөнхий нарийн бичгийн даргын́ хувьд сүүпчийн чухал илтгэл тавих болоход тэрбээр индэр дээр гарч хоёр удаа мэхийн ёслов. "Тэрбээр үг хэлэхийнхээ өмнө ийнхуү мэхийж ёспохыг төсөөлөхэд ч хэцүу байлаа. Мэхийж ёслохыг "шинэ Хятадын" үзэл сурталд харшлах упамжлал хэмээн үздэг байв. Харин Ху Зиньтао уламжлалт үзэл баримтлалд хандаж, тэдгээрийг "4 дэх уеийнхний үзэл суртпын" нэгэн эх сурвалж болгосон юм. Албан ёсны суртал нэвтрүүпэг "хятаджуулсан марксизмтай" харилцаа холбоогоо таслапгүй Күнзийн санааг олонтаа баримталж эхэлсэн. "Өв тэгш нийгэм", “дунд зэргийн чинээлэг нийгэм" бүтээн байгуулах үзэл баримтпалыг Күнзээс өвлөн залгамжипжээ. Хятад улс Өрнөдийн ардчиппын загвараас өөр улс төрийн өөрийн загварыг эрж байна хэмээн үзсэн юм. Күнзийн сургаалаас залгамжилсан ард түмнээ халамжлан анхаарах "ариун шударга төрийн эр" элитэд үпгэр жишээ болох ёстой. Харин ард түмэн нийгмийн сайн сайхан үв тэгш байдлын төлөө зүтгэх "үйлчлэх. төдий засгийн газрын” үзэл баримтлалыг санал болгосон байна.

Ху Зиньтао үнэн хэрэг дээр ийм дүр төрхтэй байхыг 
хичээж байсан. Тэрээр амьсгалын цочмог дутлын хам шинжийн өвчлөл/SARS/ гаарсан уед Гуандун мужид очихдоо эмнэлГийн ажилтнуудад мэхийн ёспож байв. Мөн Нью-Йркод бороо орж байсан ч өөрийг нь угтахаар ирсэн хүмүуст мэхийн ёспожээ. Ху Зиньтао улс орныхоо шипдэг багш нартай уупзахдаа ч бас мэхийн ёспосон байна. Ийнхүу мэхийж ёслох нь Ерөнхий нарийн бичгийн даргын нэг ёсны нэрийн хуудас болжээ. Цөөн үгтэй удирдагч "олон үг хэлэлгүй шаргуу ажиллах" гэсэн Күнзийн зарчмыг баримталж байна гэж Хятадын зарим ажиглагч тэмдэгпэжээ. Ийнхүү Күнзийн сургаалыг нэвтруүпэх биш Мао Зэдун шиг хатуу арга хэмжээ авах замаар л авипгатай тэмчэх хэрэгтэй гэж зарим хүмүус үзсэн байна. Упамжлапт үзэп баримтпалыг дарангуйлан захиргаадах хандлагыг цаашид бэхжүүпэхэд хэрэглэж мэднэ гэж хятадын пиберал сэхээтнуүд болгоомжлох өнгө аяс гаргах болов. Сөрөг үзэл бодлыг няцаан дарах “өв тэгш нийгэм" бүгдэд таапагдахгүй нь ойлгомжтой. Гэвч Күнзийн хэлснээр "ариун шударга төрийн хар хүн” нэг загварын сэтгэлгээ биш өв тэгш үзпийг эрж хайдаг хэмээн Оросын радиогийн тоймч Игорь Денисов бичжээ.

Ху Зиньтао их хурап дээр тавьсан илтгэпдээ "хятадын улс үндэстэн" гэдгийг опонтаа дурьдсан байна. "Хятадын упс үндэстний мөнхийн хөгжлийн төлөө сайн сайхан Хятадыг цогцлоон бүтээн байгуулах" тухай илтгэлийн бүр экологид зориупсан бүпэгт өгуупжээ. Ийнхуү "Хятадын упс үндэстний их сэргэн мандалт" гэсэн нь Хятад болон хилийн чанадын анхаарлыг татаад байгаа билээ.

БНХАУ-ын дарга "Хятад упс 100 жипийн ойгоороо буюу 2049 он гэхэд баян чинээлэг, хүчирхэг, ардчипсан, соёп иргэншип бүхий, төгс төгөпдөр шинэчлэгдсэн социалист улс болно" гэдгээ зарлаж упмаар шинэ тав дахь үеийн удирдпага хээл хахууль, авлигатай зоримогоор тэмцэж, бух талаар баян нийгмийг байгуупж, хүн амын дундаж давхрагыг тэлж, эдийн засгийн хөгжлийн арга хэлбэрээ шинэчпэн өөрчпөлтийг түргэсгэнэ гэдгийг цохон тэмдэгпэсэн. Намынхаа үзэл баримтлалд Марксизм-ленинизм, Мао Зэдуны үзэл суртал, Дэн Сяопиний онолыг баримталж Хятадын онциогтой социализмыг байгуупна. Ху Зиньтао одоогийн хөгжиж байгаа түвшинг "Дэлхий дээрхи хамгийн том хөгжиж буй орон" хэмээн дүгнэсэн бипээ.

Хятадын "тав дахь үеийн" удирдпагуудын бодпогын шинэ зүйлуүдийг харж болно хэмээн гадаадын шинжээчид ХКН-ын Төв Хорооны шинэ ерөнхий нарийн бичгийн дарга Си Зиньпиний анхны хэлсэн үгийг анхааралтай задпан шинжипж байна. Бээжин 


\section{Ч.Батцэцэг}

дэх Үндэсний музейд нээгдсэн үзэсгэлэнг үзэж сонирхох уеэр Си Зиньпин үг хэлэхдээ: “Хятад үндэстэнг сэргээхийг” уриапсан байна. "Өөрийнхөө төрийн эрхийг бэхжүупэх зорипгыг өмнөө тавьсан хятадын удирдагчид уламжлал ёсоор түүхэнд ханддаг юм" хэмээн Москвагийн упсын их сургуупийн дэргэдэх Ази, Африкийн орнуудын дээд сургуупийн орлогч захирал Андрей Карнеев "Голос России" /"Оросын дуу хоопой" / радиод мэдэгджээ.

Тэрбээр 1949 оны хавар Мао Зэдун тэргүүтэй намын удирдпагууд Бээжинд шилжихээс өмнө байрпаж байсан Хэбэй мужийн Сибайпо тосгонд Ху Зиньтао арван жилийн өмнө ерөнхий нарийн бичгийн даргаар сонгогдсоныхоо дараа шууд очиж байсан. Си Зиньпин мөн л адилхан замаар замнаж байгаа мэт эхлээд харагдаж байна. Гэхдээ Үндэсний музейд нээгдсэн "Сэргэн мандаптын зам" үзэсгэлэнг үзсэний дараа түүний хэлсэн үг асуудлыг арай $几$ өөрөөр тавьлаа. Түүний өмнөх удирдагч Сибайпод очихдоо хувьсгалт, коммунист өнгөрсөн уедээ ихээхэн анхааарал хандуупсан байдаг. Харин Си Зиньпиний хэлсэн үгэнд урьдын зуршип болсон улс төрийн тэмдэгпэгээ байсангүй. 1840-1842 онуудын “хар тамхи"-ны дайнаас авахуупаад өнөөг хурсэн Хятад упсын түүхэн замналыг харуупсан үзэсгэпэнг үзсэнийхээ дараа Си Зиньпин хөгжлийн социалист ирээдүйн тухай биш "Хятад мөрөөдөп"-ийн тухай ярьсан. Хэпсэн үгээс нь харахад цаасан дээр бичсэн бус өөрийнх нь үг гэж хэлж болохоор байна. Си Зиньпин өөрийн хэлсэн үгээ олон нийтийн дунд ихээхэн тархсан "Хятад улс хангапттай доромжлууппаа одоо агуу их гүрэн хэмээх нэр төрийн төлөө итгэлтэй урагшипж байна" гэсэн сэдэвд тупгуурласан байна. Си Зиньпин Хятадын өнөөгийн зорипгыг "хоцрогсодыг арилгана, зөвхөн урагшлан хөгжиж байж п өөрийгөө харуупж чадна" гэж тодорхойлжээ. "Хүн бүрийн хувь заяа, ирээдүй упс орны болон үндэстний хувь заяа, ирээдүйтэй шууд хопбоотой. Упс үндэстэн сайн байвал бүгдээрээ сайн байна гэсэн үг" хэмээн Си Зиньпин онцлон тэмдэгпэсэн байна.

Ерөнхий нарийн бичгийн даргын хэпсэн үгээс харахад "хятад мөрөөдөп" гэгч хамт опны үнэ цэнэтэй зүйл, нийт үндэстний ашиг сонирхол дээр бий болох ёстой юм байна. Си Зиньпиний хэлсэн үгээс нийгмийн тогтвортой байдлын асуудалд удирдлагууд нь нэлээд түгшиж байна гэсэн дүгнэлтийг хийж болохоор байна гэж Москвагийн Их сургуупийн дэргэдэх Ази, Африкийн орнуудын дээд сургуупийн орлогч захирал Андрей Карнеев "Оросын дуу хоолой" радиод ярилциага өгчээ. Одоохондоо шилжиптийн уеийн тухай яригдаж байна. Ер нь ирэх жилийн 3 дугаар сар хүртэл удирдагчид 
төр засгийг бэхжүулэх, дээдсийг нягтруупах, өөрсдийнхөө эргэн тойронд үндсэн бүпэглэлуүдийг нэгтгэх зэрэг гоп зорилтуудыг эхний ээлжинд шийдвэрлэх ёстой юм. Энэ уе бол хуваагдах биш эвлэлдэн нэгдэх үе юм гэж тэрбээр ярьсан байна.

Мөн түунчлэн гадаадын зарим шинжээчид Си Зиньпиний эхний алхам нь үндсэрхэг хандпагатай байна хэмээн дүгнэж байв. Үндсэрхэг үзэп руү бага зэрэг хэлбийж байгаа нь гадаад дотоод бодлогодоо консерватизмыг бэхжуүлнэ гэсэн үг биш гэж тэдгээр шинжээчид үзэж байна. Шинэ удирдпагуудьн хувьд хямрапын уед төр засгаа бэхжуүпэх нь гоп зорилт гэдгийг харуупах нь чухал байгаа, тухайн үедээ өөрчлөлт шинэчпэлийн суурь болсон Хятадын өмнөд нутаг руу Си Зиньпин эхлээд аялсан нь консерватив эргэлтт болохгуй гэдгийг харуулж байна хэмээн Андрей Карнеев үзсэн байна. Си Зиньпин сонгодсоныхоо дараа улс төрийн шинэчпэл, ардчиппын талаар нэг ч үг цухуйлгаагүй байгаа нь одоохондоо энэ хүрээнд өөрийн залгамжлагчдын нэгэн адил консерватив байдалтай байгаа бололтой.

Нөгөөтэйгүур гадны эрдэмтэн судлаачид хятадын шинэ удирдлагын нэн чухал зорилт бол эдийн засгийн шинэтгэлийг эрчимжүупэх, ирэх 10 жилийн өнгийг хэрхэн тодорхойлох тухай өөрсдийн санап дүгнэлтийг дэвшүупсээр ирлээ.

ХКН-ын шинэ ерөнхий нарийн бичгийн дарга Си Зиныпин сэтгуупчдэд хандаж хэлсэн анхны үгэндээ эдийн засгийн хөгжлийн чиг бодпогыг үргэпжлуүпнэ хэмээн мэдэгдсэн юм. Хэрэв намын өмнөх удирдагч ампалтаа хэрэгжүүпж чалсан бол Си Зиньпиний хувьд ампасан бухнээ биепуүлж чадахгүй нөхцөл байдалтай тупгарч магад гэж гадаадын судлаачид узэж байна. Тухайлбал: өнгөрсөн үед бий болгосон Хятадын эдийн засгийн хөгжлийн загвар нь үеэ өнгөрөөсөн гэж шинжээчид үзэж байна. Хятадын эдийн засгийн өнөөдрийн тупгуур нь дотоодын хэрэгпээг хөгжүүпэх явдал юм. Европ, Америкийн үндсэн хэрэгпэгчид их хэмжээний мөнгө зарцуупахад бэлэн бус нөхцөлд гадаад худапдаанд найдвар тавих нь ашиггүй гэдгийг 2008 оны хямрал харуулсан билээ.

Хүн амынхаа орлогын түвшинг нэмэгдүупэх нь зөвхөн Хятадын эдийн засгийг ч өсгөөд зогсохгүй бусад упс орнуудад тогтвортой байдпын баталгаа болно гэдэгт Оросын Упс төрийн прогноз судапгаа шинжипгээний хүрээлэнгийн захирал Андрей Виноградов итгэлтэй байна. Тэрбээр: “дэлхий нийтээрээ Хятадыг эдийн засгийн хөгжлийн зүтгүүр гэж үзэж байна. Хэрвээ БНХАУ-ын эдийн засаг өсвөл хямралын үед бүгдийг нь дэмжих болно. Одоо тус улсын өмнө 
дотоодын хэрэглээ болон эдийн засгийн өсөлтийн тэнцвэрийг опж, дотоод, гадаад зах зээпд чигпуүпэх хүнд асуудал тупгараад байна" гэжээ.

Шинжээчдийн таамаглаж буйгаар ойрын жилуүдэд хятадын ДНБ-ий өсөпт ойролцоогоор 7-7,5\%-иар өсөөд дараа нь буурч эхлэх ажээ. Хятадын статистик тоо баримт боп ил тод биш, зөвхөн БНХАУ-ын удирдпагуудын зөвшөөрсөн тоог дурьддаг гэдгийг шинжээчид сануулсаар байгаа юм.

Шинэ удирдпагуудын хувыд хямрапын уед төр засгаа бэхжуүпэх нь гол зорипт гэдгийг харуулах нь чухал байгаа гэж Москвагийн упсын их сургуупийн дэргэдэх Ази, Африкийн орнуудын дээд сургуулийн орлогч захирал Андрей Карнеев үзэж байна. "Хятад үндэстний сэргэн мандапт" гэдэг нэр хүндтэй сэдвийг өөрийн хэлсэн үгэндээ ашигпахдаа ч Си Зиньпин дээрхийг п нотпохыг оролдсон юм. 1978 оны 12 дугаар сард болсон ХКН-ын Төв Хорооны 11 дэх удаагийн 3 дугаар чуупганы бүгд хурапдаан дээр Дэн Сяопины үг хэлж байгаа хөрөг зургийн өмнө Си Зиньпин зогсож байгаад үгээ хэлсэн нь учиртай. ЯГ энэ үеэс п шинэчпэл, нээпттэй ип тод байдал эхтэй бипээ гэж тэр ярьсан байна.

Юуны өмнө БНХАУ гадаад бодпогоо эдийн засагжуупахад анхаарлаа хандуулж байна. Олон упсын эдийн засгийн хэрэг эрхлэх газрыг БНХАУ-ын Гадаад Харилцааны Яаманд байгуулжээ. Энэ алхам Хятадын удирдпагаас эдийн засгийн дипломат ажиппагаанд улам их анхаарал тавьж байгааг тусган харуулсан гэж Оросын ШУА-ийн Алс Дорнодын хүрээлэнгийн дэд захирал Сергей Пузянин үзэж байна. Шинэ газрыг байгуупах тухай XKH-ын XVIII их хурал нээгдэхээс нэг сарын өмнө зарлаж мэдээлсэн байна. Их хурлын үр дүнд засгийн эрхэнд гарсан шинэ уеийнхэн ойрын 10 жилийн улс орныхоо галаад дотоод бодпогыг тодорхойпох бопно. Энэ завсар Хятад упс ДНБ-нийхээ хэр хэмжээгээр одоо дэлхийд тэргуупж байгаа АНУ-аас давах тэмдэгпэлт үйл явдал болно гэж эдийн засагчид таамагпаж байна. Хятадын дотоодын хөгжлийн хэрэгцээ, эдийн засгийн аюупгуй байдлыг хангах явдал дипломат ажилтнуудаас эдийн засагт илуү их анхаарал тавих гол шалтгаан болсон гэдгийг тэмдэглэсэн.

Гадаад бодпогын бусад чиглэлийн нэгэн адип эдийн засгийн дипломат ажиплагааны зорипго, зорилтыг хятадын нийгэмд радикал эх оронч ба үндсэрхэг үзэл гаарсан нөхцөлд тодорхойлох юм. Энэ нь удирдлагад нөлөө үзүүпэх нь дамжиггүй. Харин Хятадын 5 дахь үеийн удирдагчид тэсвэр тэвчээртэй байж, хүчирхэг боповч 
даруухан хариуцлагатай гүрэн улсын дүр төрхийг урагш ахиулах нь улс орны ашиг сонирхолд нийцэж байгааг ойлгож байна гэж профессор Сергей Пузянин үзэж байна.

Хятад упсад хөрөнгө оруупаптын үсрэпт бас хор хохироп дагуулах болжээ. Тухайлбал үйпдвэрлэлийн илуүдэл нь гадаадын зохисгуй тухайн байдалтай холбоотойгоор олон үйлдвэр дампуурч, ДНБ унахад хургэж мэднэ. Иймээс хятадын шинэ удирдиагын нэн чухал зорипт эдийн засгийн шинэтгэпийг эрчимжүүпэхэд оршино. Шинэтгэл хөгжлийг упам тэнцүу болгоход чигпэгдэх ёстой гэж Оросын ШУА-ийн Алс Дорнодын хүрээлэнгийн дэд захирал Сергей Пузянин "Оросын дуу хоопой" радиод өгсөн ярилцлагадаа тэмдэгпээд, «эдугээ Хятад упс дорвигуй эдийн засаг, түрэмгий экспорт, технологийг хуупбарлан ашиглах явдапд тулгуурласан хуучин ба шинэ загваруудын уупзвар дээр байна. Шинэ загвар фотоодын эрэлтийг ашиглах, дэлхийн инновацийн төвийг Хятад упсал байгуупах явдлыг түшиглэж байна. Үүнд: Хятад упс үндэстний сэтгэлгээтэй холбоотой тулгуур асуудал гарлаа. Хятадууд бол хатуу сахилгатай маш сайн гүйцэтгэгч, зиндааг чанд баримтлагч, үйл явц технологийг сайн хуулагч гэдгийг өмнөх хэдэн арван жил нотпон харуулав. Гэвч тэд бүтээпч үйл ажиппагааг систем болгоход сайн биш, бас дээр нь хариуцлага өөртөө ногдуулах, эрсдэлтэй боловч урагш ахихад туслах шийдвэрийг санаачпах цургүй” гэжээ. Энэ бүхэн инноваци маягийн эдийн засаг Хятад упсад байгуупахад саад болно гэж профессор Пузянин үзэж байна.

Бусдын боловсруулалтыг хуупан ашиглаж дассан Хятад улс дэлхийн “фабрик"-аас инновацийн төв болж хувирах амаргүй замыг арга буюу туулах юм. Түүнээс гадна Хятад улс эдийн засгийн шинэ загварыг дөнгөж байгуупж эхлэв. Эдийн засгийн өнөөгийн загварын зохисгүй тап болон гадаадын зах зээлээс хэт хамааралтай байх явдлын уршиг мэдрэгдэнэ. Си Зиньпиний баг эдгээр саад тотгорыг давж, хөгжлийг тогтонги болгож, нөөцийн ашиглалтад шинээр хандах үзэл санааг төлөвшүүпж, экологийн ба хүн ам зүйн асуудлыг шийдвэрлэх ёстой. Өсөлтийн хурдыг хамаагүй нэмэгдүуээк ‘орилго тавихгүй. Гэвч хятадын удирдлага нийгмийн тогтонги байдлыг хэвээр хадгалахад зайлшгуй өсөптийн хэмжээг хангах ёстой гэж доктор Пузянин дүгнэлээ.

Нөгөөтэйгуур Хятадын хөрөнгийн бирж дээрхи юаний үнэт цаасны арилжаа нь гадаадын хөрөнгө оруулагчдын чиг шугамыг тодорхойпдог бипээ. Чухамдаа хятадын хөрөнгө оруулагчдын зүгээс тэд өрсөлдөөнийг олж харваас энэхүу тогпоом сая сэтгэл 
татаж, хорхой хүргэх аж. Ийм орчныг байгуупах нь хятадын эрх баригчдын хувьд хамгийн хүнд зорипт болоод байна. "Өнөөдрийн байдпаар Хятадын төлөвлөгөөнууд нь зарчмын хувьд хөгжиж байгаа санхүүгийн төвийн хувьд болон гадаадын хөрөнгө оруулагчдын сонирхолын хувьд нийцэж байна. Ингэхдээ дэлхийн санхуүгийн зах зээл дээрх байдал нь бусад олон хөгжиж байгаа орнуудын нэгэн адил, хятадын зах дээр идэвхитэй хөрөнгө татахад нөлөө үзуүпэхгүй байна: Хязгаарпалтыг цуцлаж, квотыг нэмэгдуүлюж байгаа энэ байдал нь гадаадын хөрөнгө оруулагчдад Хятадын дотоодын хөрөнгийн захын худалдааг ашиглах боломжуудыг олгож байна" гэж Оросын санхуүгийн шинжээч Игорь Костиков үзжээ.

Хятадын шинэ удирдагчдаас дэлхий дахин хүпээж байгаа бас нэг апхам бол үндэсний валютаа бэхжүулэх талаар авах арга хэмжээ билээ. Тэгэхдээ энд дэпхийн зах зээлийг апдах аюуп байгаа гэдгийг Хөрөнгө оруупалт санхүүгийн "Метрополь" компанийн шинжилгээний департаментийн захирал Марк Рубинштейн анхааруупж байна. Үүнд: “Энэ асуудап зөвхөн эдийн засгийн ч бус упс төрийн асуудал юм. Хэрвээ хятадын бараа гадаадад үнэтэй болвол тэдний хэрэгцээг багасгаж хятадын эдийн засгийн хөдөпгүүр болсон экспортыг хорогдуупж мэдэх юм" гэж тэрбээр ярьжээ. Упмаар хэрэгпээний нөхциийг сайжруупахын тупд упс доторх зээплэгийг хөгжуүпэх шаардпагатай гэж үзэж байна. "Банкуудыг хэрэгпээний зээплэгэд урамшуупах шаардлагатай байна. Бүр апбан газрын батлан даалттай зээлпэгийн хагасыг нь хэрэглээний зээлиэгэд шилжүүпж болох юм. Хувийн зээлдэгчдийн хүуг ч багасгах шаардиагатай болж мэднэ" гэж мэдэгдсэн байна.

"Валютын дайны" тухай хэзээ ч мартаж болохгуй. Хятад улс Вашингтонд зохих хэмжээний буупт хийгээд байгаа гэхдээ америкчууд тус улсаас ипуу их буулт хүпээх хэрэггүй $~$ болов уу. Экспорт унана гэдэг нь ямар аюултайг Москвагийн их сургуулийн дэргэдэх Ази, Африкийн орнуудын дээд сургуупийн багш Александр Габуев ийнхуу тайлбарлаж байна. "Экспорт бол үйлдвэрлэл нэлээд гүн нягтарсан БНХАУ-ын зүун өмнөд нутагт тус упсын иргэдийг ажлын байраар хангаж байгаа салбар юм. Хэрвээ экспорт огшом унавал тэнд нийгмийн давалгаа уүснэ. Энэ давалгааг хэрхэн яаж дарах нь ойлгомжгүй байна. Энэ талаас нь авч үзвэл хятадын удирдпага өөрсдийгөө эвгүй занганд оруупах болно. Гэхдээ байдал хэрхэн өрнөхийг бид харах болно. Ер нь нөхцөл байдал хүндрэлтэй байна" гэжээ.

Хятадын бараа Европ тивд ямар уүрэг гүйцэтгэж байгааг 
мартах ёсгүй, Бээжин ямар нэг асуудалтай тупгарахыг тэнд нэг их хүсэхгүй байгаа. Өнөөдөр хятадын байдал дэпхий дахиныг мөнгөний ханшийн унаптаас хамгаалж байгаа гэж эдийн засагч Дмитрий Тратас үзэж байна. Тэр "Америк, Европын эцийн засаг мөнгөний ханшийн уналтыг хангапттай доод хэмжээнд барихад нь Хятад упс туспаж байгаа юм. Европийн бүсийн болон АНУ-ын санхуүгийн зохицуупагчид сүүпийн уед санхүүгийн зах зээпийг бэлэн мөнгөөр асар хүчтэй дүүргэж байсан нь нууц биш ээ. Оноп ёсоор бол үүнээс болж мөнгөний ханш зад тавих ёстой гэтэл ийм үйл явдал болохгүй байна. Энэ нь хятадын экспортын хямд бараанаас шууд шалтгаалґж байгаа" гэсэн дүгнэлтэнд хүрчээ.

Олон улсын Moody's рейтингийн агентпагийн үнэлснээр 2013 онд Ази-Номхон далайн бүс нутаг дэлхийн өөр бусад бус нутгаас илүү эрчимтэй хөгжих явдал юм. Хятад улсын өсөпт удааширсан ч хурд нь эрс унахгуй. Ази-Номхон далайн бүс нуггийн орнууд макро эдийн засгийн өндөр узуупэптийнхээ ачаар эрсдпийг давж мэднэ гэж Moody's агентпаг үзэж байна. Түүнээс гадна эдгээр улс өсөлтийн дотоодьін эх сурвалжид илуу их тупгуурлах болсон гэж агентлагийн дэд ерөнхийлөгч Кристиан де Гузман мэдэгджээ. Хятадын макро эдийн засгийн байдалд өгсөн үнэлгээний тухайд гэвэл Moody's агентпагийн таамаглал Олон упсын вапютын сангийн шинжээчдийн дүгнэлттэй нийцжээ. Бүр 2012 онд тэц Хятад упсын эдийн засгийн хөгжлийн хурл гарцаагүй намжихад анхаарлыг хандуупсан билээ. Хятал улсын ДНБ-ий ойрын өсөлтийн барагцаалбал тэн хагас нь капиталыг нэмэгдуүпэхэд ногдсон гэж ОУВС тэмдэглэсэн байна. Өөрөөр хэлбэл компаниуд хөдөлмөрийн бүтээмжийг дээшлуупэх биш үйлдвэрлэх хэрэгспийг нэмэгдуүиэхэд хөрөнгө оруупжээ. Ийм стратеги ипуудэл ажиплах хүчинтэй нөхшөпд үр дунд хүрнэ. Харин 2015 оноос хойш Хятад упсад ажиплах хүчин багасаж, энэ улс өрсөпдөх давуу тапаа апдаж мэднэ гэж хүн ам зүйчид үзэж байна. Түүнээс гадна дэлхийн эдийн засгийн доройтол хятадын гадаадын зах зээлийг баримжаалах үйлдвэрүүдийг хамрахгүй байж чадахгүй. Ийм хандлага Ази-Номхон далайн бүс нутгийн эдийн - ссгийг бас хамарсныг Moody's агентпагийн шинжээчил онцопжээ. Тэдний үнэлснээр бус нутгийн корпорациудын өрсөлдөх чадварын үзуүлэлт тогтонги хэвээр байсан ч цэпхийн эдийн засгийн хөГжлийн хурд удааширсан явдал бутээгдэхүүнээ гадаадад гаргадаг компаниудын байдапд зохисгүй нөлөөлж мэднэ.

БНХАУ нь эдийн засгийн өсөлтөөрөө дэпхийд тэргуүпэх тухай прогноз таамаглалыг дэлхийн улс орнууд дэвшуупсээр байна. 
Тухайлбал: бүр 2017 онд АНУ эдийн засгийнхаа хэр хэмжээгээр БНХАУ-ын дараа орно гэж "Pricewaterhouse Coopers консаптинг компани"-ий шинжээчид таамагпап дэвшуүлж байна. Харин дэлххийн эдийн засагт хүчний сэпгээ үүгээр төгсөхгүй гэж тэд үзээд, 2050 он гэхэд БНХАУ, АНУ, Энэтхэг упсуудын эдийн засаг тэргуун гурван байрыг эзэлнэ гэж тус компанийн шинжээчид дүгнэсэн байна. Тэгвэды АНУ, БНХАУ-ын дараа хоёрдугаарт орж, Энэтхэг улс өнөөгийн 10 дугаар байрнаас эрс урагшипж гуравт орох болно. Хэтдээ БНХАУын ДНБ бүр 54 их наяд хүрнэ. Эдүгээ мөн үзүүпэлт 6 их наяд хүрэхгүй байгааг харьцуупж үз п дээ. Хятад улс эдийн засгийн хөгжлөөрөө дэлхийд тэргүупнэ гэж Орос-Хяталын танхимын хариуцлагатай нарийн бичгийн дарга Сергей Санакоев үзэж байна. Тэрээр Хятад упс ойрын үед ийм өндөр амжилт гаргахыг тайлбарлан хэлэхдээ "Упс үндэстэн ажилпаж, үйлдвэрпэн бүтээж байна. Энэ нь өсөлтийн нэн чухал хүчин зүйл юм. Мэдээжээр дэлхийн санхүүгийн хямрал гарсан нөхцөлд Хятадын бараа таваарын эрэлт дэлхий даяар унасан нь Хятадын эдийн засагт нөлөөлсөн. Гэвч дотоодын эрэлт хэрэгцээг баримжаалах шуурхай арга хэмжээ авч, зээпийн уян хатан бодпого явуулж, эдийн засгийнхаа өсөлтийн жилийн дундаж хурдыг 710 хувь байлгах боломж олгов. Энэ нь бур 2017 онд Хятад упс тэргүүпэх эдийн засагтай болоход хангапттай» гэсэн байна.

НөгөөтэйгүҮр БНХАУ-ын шинэ удирдагч Си Зиньпин, Пи Кэцян нар анхны хэлсэн үгэндээ авилгатай хийх тэмцэлд гойд анхаарап тавьсан билээ. Авипгатай хийх тэмцэл болон “Цэвэр ариун засгийн газрыг" эмхлэн байгуулах явдал "хятадын мөрөөдлийр" биепуупэх замд хэрэгжүупэх нэгэн зорипго гэж БНХАУ-ын дарга Си Зиньпин чуулганыг хаах ёспоп дээр, Төрийн зөвлөлийн ерөнхий сайд їи Кэцян сэтгуүпчдийн өмнө хэпсэн үгэндээ онцолсон нь тохиолдпын хэрэг биш юм. Үүнийг бүгд хүпээн зөвшөөрөх улмаар ийм замаар улс орноо хүчтэй донсопгооноос аварч болно гэж удирдагчид узжээ.

Пи КэцЯн сэтгүупчдийн өмнө үг хэлэхдээ, Күнзийн цэцэн мэргэн сургаапд хандсан нь "хятадын мөрөөдөп", "хятадын онцлогтой социализм»-ын үнэт зүйл төдийгүй урьдын оюуны өвийг эргэцүүпэн бодоход тулгуурлаж байгааг харуупсан гэж ажиглагчид үзжээ. Пи Кэцян авилгатай хийх тэмцлийн төлөө засгийн газрын хариуцлагын талаар өгүүпсэн юм. Тэрбээр эртний мэргэдэд бас хандаж «Түшмэлийн апбан тушаал ба баяжих эрмэлзэл бол хоёр өөр зам гэж эрт дээр уед өгуүпж байв. Түшмэп нэгэнт төр засгийн албан тушаал хашиж байгаа бол олон нийтийн ашиг сонирхопд $\pi$ 
үйлчилж, баяжих эрмэлзэлээ орхих ёстой. Биднийг бух нийгэм, хянаж шалгаасай. Хахууль авч хахуульдагч бопохгүй байх, авилгатай тэмцэх зэрэг механизмыг боловсронгуй болгох нь зайлшгүй чухал. Хахуульдах ажиплагаa ба хахуупьдагчдыг хатуу шийтгэх хэрэгтэй" гэж хэлєэн байна.

"Хятадын мөрөөдөл" бол нэлээд хийсвэр үзэл санаа гэж олонх шинжээч тэмдэглэжээ. Энэ үзэп санаа ямар агуулгатай бопохоос төр засгийн нэр хүнд болон Хятадын өнөөгийн тогтолцооны байдал, тогтвортой хөгжил шалтгаална. Авилгатай тэмцэх бодпого түшмэдийн эрхийг хязгаарлах зохих механизм, тэдний ажлыг ил тод болгох арга хэмжээгээр батпагдвал иргэд ийм бодпогыг нааштай хүпээж авах нь дамжиггүй. Өнөөгийн удирдагчид "цэвэр ариун засгийн газрыг «эмхлэн байгуулах эсэхээс хүний сайн сайхан аж байдал, упс орны тогтвортой хөгжил хамаарахыг олонх нь ойлгож байна. Тэгсэн цагт “эх оронч бодит бодпого" баримтпах Хятадын шинэ удирдагчид үүргээ биепуүпж болох юм.

Улмаар ХКН-ын Төв Хорооны Ерөнхий нарийн бичгийн дарга Си Зиньпин хурапцаан дээр шүух, прокурорын газар, аюупгүй байдлын байгуулпагуудад хандан хууль хөдөлбөргүй даган мөрдөхийг уриапсан бөгөөд Си Зиньпин авилгатай тэмцэж, төр иргэний хоорондох зайг ойртуулахаар ажиплана гэж ампасан. Тэгснээр шинэ удирдлага авилга, хээл хахуупьтай шийдвэртэй тэмцэнэ гэдгээ харуупж эхэлпээ. Их хурлын дараа бус нутгийн төрийн албан хаагчид хэдэн арваараа авилгын хэргээр мөрдөн байцаах газрын анхаарлын төвд орлоо.

Ийнхуү ХКН авилгатай упам хүчтэй тэмцэх болсон нь Хятадаас капиталаа гаргахад ташуур өгч, хахууль аван упсын сангийн хөрөнгө тоносон түшмэд үп хөдлөх хөрөнгөө яараптай худапдаж эхлэв. Урьдын харилцаа холбоо нь хөрөнгөө гадаадад нууцаар гаргаж, хилийн чанадад суух бичгийг тойруу дапдуур замаар авах боломж тэдэнд опгох болжээ. Тансаг орд харшаа 2012 оны 11 дүгээр сараас худапдаж эхэпсэн бөгөөд 12 дугаар сар гэхэд худапдаa өргөжин эрчимжсэн гэж ХКН-ын Төв Хорооны Сахипга батыг хянан шалгах хорооны иптгэлд тэмдэгпэсэн байна.

Томоохон зургаан хотын дарга, дэд дарга нарыг төдөлгүй огцруупав. Түшмэдийг баривчилж, апбан эрхээ хэтрүүпж, улсын хөрөнгө шамшигдуулсан туп эрүүгийн хариуцлагад татжээ. Өнгөрсөн онд 100 гаруй авилгачдын талаар ийм арга хэмжээ авсныг Оросын Упс төр судлал, прогноз төвийн удирдагч Андрей Виноградов дурьдаад: “авилга бүх төрпийн засаг - хошуу мужийн удирдлага, 
дээд удирдпагад нэвтэрсэн байна. Авилгатай хийх тэмциийн тухайд гэвэл амжилт гаргаагуй мэт сэтгэгдэл төрж магадгүй. Энэ нь ХKН-аас авилгатай муу тэмцэж байгаа биш авилга төлөвлөгөөт эдийн засгаас зах зээлд шипжих уеийн зайлшгүй дагууп болсонтой холбоотой. Хятад упс ийм нийгмийн нэг" юм гэв.

Хятад упсад баривчипсан авлигачдын тоо өсөн нэмэгдсээр байна. Үүний сануу шипмэл орд харшаа худапдаж, мөнгө хөрөнгөө хилийн чанадад гаргасан түшмэдийн тоо ч нэмэгдэж байна. 2012 онд улсын 10 мянга орчим албан хаагч ийм ажилпагаа явуупж, упс орноосоо зугтан зайлжээ. Тэд упсад 160 тэрбум гаруй долларын хохирол учруупсан байна. Байдлаас харахад капитал гадагшаа гарах үйл явц зогсохгүй байна. Харин ч Бээжин, Шанхай, Гуанжоугийн үп хөдлөх хөрөнгийн зах зээлүүд орон сууцны шилмэл байшин, тансаг орд харш худалдах саналаар дүурчээ. Тухайлбал: Шар тэнгисийн эрэг хавийн нэрд гарсан Бэйдахэ амралт сувилпын газар болон Хайнань арал дахь үп хөдлөх хөрөнгөө худалдахыг олон этгээд оропдож байна. Худалдан авагч бэлэн мөнгөөр авбал өртөг нэлээд буурах юм. Авпигачид орпогоо хилийн чанадад их хэмжээгээр гаргах ажилпагаа компани, үйлдвэрпэл эрхлэгчид капиталаа Хятад упсаас гаргахтай цаг хугацааны хувьд давхцаж байна. 2012 онд тэд 225 тэрбум доплар гаргажээ. Энэ нь Хятал упсын 2011 оны ДНБий бараг 3 хувь гэсэн үг. Капиталыг нууц сувгаар гадаадад гаргаж байгаа жишээ олон байгаагаас дурьдвал, бэлэн мөнгийг гаалийн хяналт шалгаптгүйгээр хувийн онгоцоор тээвэрлэн шилжүупэх гүүрийг байгуупжээ. Түүнчлэн их хэмжээний бэлэн мөнгө цүнхэндээ хийж хил давуулах этгээдуудийн үйлчилгээ эрэлт хэрэгцээтэй байна. Компаниуд ажилтнуудынхаа хөрөнгө мөнгийг хилийн чанадад гуйвуулах банкны хөрөнгөд багтаах тохиолдол олонтаа гарч байна. Түүнээс гадна компаниудын эзэд хувьцаагаа Хонгконг, Сингапур, Нью-Йоркийн хөрөнгийн биржийн зах зээлд худалдаж хөрөнгетэй бопох нь ердийн ажиппагаа бопжээ. Хэргийг нь шүүн таслах ажиллагаанаас эмээж зугтсан упсын түшмэд болон хөрөнгөө гадаадад гаргаж байгаа үйлдвэрлэл эрхлэгчид хөрөнгөө үл хөдлөх хөрөнгөд оруулж байна. Тухайлбал өнгөрсөн онд хятадууд 7 тэрбум доппараар үп хөдлөх хөрөнгө авсан тухай АНУ-ын үндэсний худапдагчдын хопбоо мэдээпжээ.

"Шинэ хятадуудын" байрлах орон сууцны бүйэл бүгэн хороолпуд Пондон болон Франц, Итали, Грек, Кипр зэрэг улсын амралт сувиппын газруудад бий болсоор байна. Тэгэхдээ орд харшийг тусгай төспөөр барьж, эдлэнг хятап маягийн сэруүн асар 
болон алтан загастай цөөрмөөр чимэгпэж байна. Энэ нь орон нутгийн энгийн оршин суугчдын хувьд хятадын түрэмгийлэл гэгчийн тод нотолгоо болж, хятадын эсрэг үзэл санааг гааруулж байна хэмээн гадны хэвпэл мэдээппийн хэрэгспэлууд мэдээлж байна.

XKH-ын XVIII их хурал дээр экологийн соёп иргэншпэлийн бүтээн байгуупалтыг бүхий талаар хийх асуудлыг дэвшүупж тавьсан бипээ. Өнөөдөр Хятадын байгалийн тэнцвэрт байдал, цаг уурын түүхэнд гарч байгаагүй үзэгдэл, шороон шуурга, агаарын бохирдол хирээс хэтэрч байгаa талаар гадны хэвпэл мэдээлпиийн хэрэгспэлууд мэдээпсээр байна. Хятад упс орчны бохирдпоосоо ангижирсан тэр цагт ажиглагдаж буй өмнө цаг уурын түухэнд гарч байгаагүй байгалийн ер бусын үзэгдиүудтэй тэмцэхэд хялбар байх болно. Хятадын төвийн болон зүүн бүс нутгуудын өтгөн манан, тортог болон утаатай тэмцэх ажлыг Оросын шинжээчид ийн тайлбарлаж байна.

Хятадын агаарын маш өндер даралт болон хортой хий ба хортой бодисуудын хэмжээ их байна. Тухайлбал: автомашины утааг хэлж болно гэж Оросын ШУА-ийн Алс-Дорнодын хүрээлэнгийн шинжээч Игорь Ушаков ярьж байна. Гэрээр 20 сая хүн амтай Бээжинд 4 сая автомашин явдаг бөгөөд энэ нь бусад хотуудын тээврийг оруулалгүйгээр гаргасан тоо гэдгийг сануупав. Энэ нь ямар нэгэн байдпаар экологийн суйрэл гэж тэр тэмдэгпэжээ. «Энэ нь хүний буруу үйл ажиллагаатай холбоотой. Үзэгдэл нь хиймэп шинж тэмдгийн нэгэн адип байгапийн шинж тэмдэгтэй байдаг. Энэ бол хятаддуудын хувьд тулгамдсан асуудал. Одооноос нийгмийн үр дагавар гарч эхлээд байна. Хятад улсад өнгөрсөн жил байгальь орчны байдалтай холбоотой эсэргуүцлийн жагсаалын тоо 30 хувиар өсчээ.

Усны бохирдлын талаар “Чайна дейли” сонинд Шар мөрний өмнуур оршин суудаг хүмүусийн орчин нь хүнд металпын упмаас бохирдсон туп 50-иас ипуу наспахгуй хэмээн бичжээ. Өнгөрсөн хавар Бээжинд болсон манангийн тухай хятадууд ип тод бичиж, ХКН-ын их хурал дээр сайхан Хятадын тухай ярьж байсан, гэтэл тэнгэр тэр чигээрээ хар байх юм гэж асуудлыг нэлээд шупуухан тавьж мэдээпсэн байна. Хятадын тэнгэрийн манан, утаа, униар энэ бүхэн нь шинжээчдэд шинэ түгшүур дэлдэх шалтгаан бопж байна. Эрчим хүчийг болон бусад сапбаруудыг яаралтай илүу цэвэр эрчим хучний эх үүсвэрт шилжүупэх шаардпагатай байна гэж “Дэпхийн онгон байгапь сан"-гийн Түпш-эрчим хүчний цогцолборын экологийн бодлогын хөтөлбөрийн тэргүүн Алексей Книжников “Оросын дуу 
хоопой" радиод ярипциага өгчээ. Тэрбээр “Хятадын эрчим хүч одоо болтоп үндсэндээ нүүрсэн дээр суурипж байгаа. Энэ нь агаарыг маш их хэмжээгээр бохирдуупж байдаг нь ойлгомжтой. Үүнтэй холбогдуупан экологийн цэвэр түлшийг нэмэгдүүпэх шаардлагатай байгааг тэмдэгпэх нь зүйтэй юм. Хятад улсад эрчим хүчийг нүүрснээс байгалийн хий руү шипжүүпэх хийн хоолойнуудыг барих хэрэгтэй» гэЖээ.

Мөн сүйрэл гарах заналхийлэл байгаа тухай Оросын ШУАийн Алс Дорнодын хүрээлэнгийн шинжээч Андрей Островский сэтгүүпчийн асууптанд хариулахдаа, “одоо экологийн сүйрлийн бүсэд Хятадын нутаг дэвсгэрийн долооны нэг орчим хувь хамрагдаж байна. Ингэхдээ Бээжинд хамгийн өндөр түвшинтэй байгаа бөгөөд экопогийн аюупын зургаа дахь түвшинтэй байгаа, хэрвээ салхигүй, агаарын өндөр даралттай байвал сүйрэл гарч болзошгүй юм" гэсэн байна.

Нөгөөтэйгуүр "Жунго зинзи шибао" сонинд “нэг гэр бүп - нэг хүүхэд" зарчмаар хуүхэд төрөлтийг хязгаарлах бодиогоос аль болох түргэн татгалзахыг уриалсан хятадын эрдэмтдийн нийтпэп гарсан байна. Үүнд дээрх бодпогоос татгалзсанаар хүн амын бүтцэд өндөр настай хүмүусийн хувийг багасгаж, ажиллах хучин дутагдах асуудлыг шийдвэрлэж болно гэж бичжээ. Хятадын шинжээчид хүухэд төрөлтийг хязгаарлах бодпогыг зөөлруүпэх асуудлыг аль хэдийнээ хэлэлцэж эхлээд байна. Гэвч асуудлыг нэн даруй шийдвэрпэвэл зохино гэсэн өгуүплийг анх удаа нийтэпжээ. Ялангуяа БНХАУ-ын Төрийн Зөвпөпийн дэргэдэх Хөгжлийн судлалын төвийн ажилтнууд хүн ам зүйн бодлогыг хянаж үзэхийг санаачилсан нь олны анхаарлыг татсан юм. Энэ нь засгийн газрын эрдэм шинжипгээний нэгэн төв аж.

Шинжээчидтомоохонхотуудадхуухэдтөрөлтийнкоэффициент эрс доройтсоныг онцопсон байна. Энэ узуупэлт упс даяар 1,6\% ойртож, хүн амын өрийн хорогдлыг нөхөх аргагүй болсон. 1970аад оны сүүпчээр хүүхэд төрөлтөд хатуу хяналт тавьж эхэпсэн нь хүн амын бүтцэд өндөр настай хүмүүс зонхипоход хүргэпээ. Үүний сацуу хөдөлмөрлөх чадвартай хүмүусийн тоо хөдөпбөргүй багасч байна гэжээ. Хятадын шинжээчдийн хийсэн ийм дүгнэлт олон упсын үнэпгээнд нийцсэн байна.

НҮБ-ын урьдчилан таамагпаснаар өнөөгийн байдал хэвээр хадгапагдвал 2050 он гэхэд Хятад улс ажиппах хүчнийхээ барагцаалбал 17 хувийг апдаж мэдэхээр байна гэжээ. Хятадын эрдэмтэд эдийн засгийн хөгжлийн өнөө үед хоёр хуүхэдтэй байхыг бух гэр бүлд зөвшөерч болно гэж үзсэн байна. Энэ нь 30 хүрээгүй 
хятад хүмуүсийн тэн хагас гаруй нь хоёроос илүү олон хүүхэдтэй болохыг эрмэлзэхгуйг харуулсан санал асуулгын үр дүнд нийцжээ. Иймээс хүн ам зүйн "тэсрэлт" болохгүй. Нөхцөл байдал улс орны өнөөгийн хөгжлийн тувшинд нийцэх юм.

Хүн ам зуйн өнөөгийн бодпогыг цаашид үргэлжлуүпэх нь улс орны эдийн засгийн хөгжлийн ашиг сонирхолд харшилж байна. Учир нь хөдөлмөрийн асар их хэмжээний нөөц Хятад упсын давуу тал ямагт байсан гэж Оросын ШУА-ийн Алс Дорнодын хурээлэнгийн дэд захирал профессор Сергей Пузянин үзэж байна. Тэрээр хэлэхдээ: «Миний бодоход Хятадын удирдпага одоогоос таван жипийн өмнө шинэтгэл ид явагдаж, эдийн засгийн гайхамшигт үр дүнд хүрсэн үед хүн ам зүйн бодпогод засвар оруулах байсан. Амжилт, ДНБ-ний өсөлт эгэл жирийн хүмүүсийг умартахад хүргэв. Үүний упмаас хүн ам зүйн асуудал эн түруүнд гарсан” гэж дүгнэжээ. Дээрх асуудалтай холбогдуупан Хятадын дотоодын интернэтийн сүлжээгээр гарч буй тайлбараас узэхул, опюн нийт хуүхэц төрөлтийн төлөвпөгөөт бодпогыг зөөпрүүпэх арга хэмжээг сайшаан дэмжсэн байна.

\section{ДҮГНЭИТ}

Ийнхуү өнгөрсөн онд хуралдсан XKH-ын XVIII их хурал нь дэлхий нийтийн анхаарлын төвд байсан нь БНХАУ-ын ойрын 10 жипийн хөгжлийг тодорхойпох, шинэ удирдпагаа сонгосон явдалтай холбоотой байсан юм. Оросын эрдэмтэн судпаачдын үзэл бодол, дүгнэлт, байр суурийг хэвпэл мэдээппийн хэрэгспэлээс сонгон авч дараах дүгнэлтэнд хүрлээ.

Оросын эрдэмтэн судпаачид ХКН-ын XVIII их хурпаар дэвшүүпсэн "Хяталын упс үндэстний их сэргэн мандалт" буюу хятад үндэстэн:г сэргээх тухай апхам нь үндсэрхэг хандиага, үндсэрхэг узэл руу бага зэрэг хэлбийж байгааг иллтгэж байна. Мен "хятал мөрөөдөп"-ийг нэлээд хийсвэр үзэл санаа гэж олонх шинжээч тэмдэглэж, "хятад мөрөөдөп" гэгчийг хамт олны үнэ цэнэтэй зуйл, нийт үндэстний ашиг сонирхол дээр бий болгох ажээ гэсэн таамаг дэвшүУПСэн юм.

Үүнээс гадна Хятадын эдийн засгийн өнөөгийн хөгжлийг тодорхойлохдоо, дэлхий нийтээрээ Хятадыг эдийн засгийн хөгжлийн зүтгучр гэж үзэж байна. Хэрвээ БНХАУ-ын эдийн засаг өсвөл хямралын үед бүгдийг нь дэмжих болно. Хүн амынхаа орпогын түвшинг нэмэгдүүиэх нь зөвхөн Хятадын эдийн засгийг ч өсгөөд зогсохгүй бусад улс орнуудад тогтвортой байдлын баталгаа болно гэсэн дүгнэлтэнд хүрчээ. УПмаар цаашид шинэ удирдлага 
эдийн засгийн шинэтгэлийг хэрхэн явуулах, валют, санхуугийн хямралыг зохицуулах, хөрөнгө оруупалтын талаарх асуудпыг хөндөж тавьжээ.

Нөгөөтэйгүур нийгмийн тогтвортой байдпын асуудалд Хятадын удирдпагууд нэпээд түгшиж байгаа талаар санал бодлоо илэрхййлж, шинэ удирдла̊гуудын хувьд хямрапын үед төр засгаа бэхжүүпэх нь гоп зорилт гэдгийг харуупах ёстой гэж дүгнэсэн байна. Өнгөрсөн уед бий болгосон Хятадын эдийн засгийн хөгжлийн загвар нь үеэ өнгөрөөсөн хэмээн зарим шинжээчид үзжээ. Упмаар Оросын эрдэмтэн судлаачид Хятадын шинэ удирдлага авлига хээл хахуупьтай хэрхэн тэмцэж байгаа, ямар сөрөг үр дагавар дагуулж буй, байгаль экологийн асуудал, хүн ам зүйн өнөөгийн бодлогын талаар тус бүрд нь өөрийн үзэл бодлоо илэрхийлж, дүгнэлт, тайлбар хийснийг багтаасан болно.

\section{АШИГПАСАН МАТЕРИАЛ:}

1. "Жэнминь жибао" 2013.03.03

2. http//news.xinhuanet.com/politics/2013-03/03/c_ 124408203_2.htm

3. Коппаж: "Голос России"

4. Хятад упсад болж байгаа үйл явдал ба Орос упсын байр суурь (192 материал) http://mongolian.ruvr/ 108251553/index. html.

5. Цзян Фэн. Инновационная политика: международный опыт (Китай) journalistic @rambler.ru

6. http://chelt.ru/new/?p=1545

7. http://www.olloo.mn/modules.php?name=news\&file=article\&s $\mathrm{id}=12$

8. http://www.tsahimurtuu.mn/index. php./component /2/itemlist/user/flickr.com/firz/cc-by-nc-sa 30

9. “Өгпөөний сонин" 2013-04-17 /Мэдээний дүн/

Abstract: The paper aims to examine the proceedings, significance, and specialty of the 18th National Congress of the Communist Party of China and the new rulership of 'the fifth generation' and the state of socio-economic development of China in the opinion of international, in particular Russian researchers.

Keywords: the Communist Party of China, National Congress, new rulership, political and socio-economic development 